\title{
Badania numeryczne tworzenia metodą LPCS powłoki z cyny na podłożu aluminiowym
}

\section{Numerical simulations of Low Pressure Cold Spray method tin coating on aluminum substrate}

\section{Streszczenie}

W pracy przedstawiono możliwość zastosowania obliczeń termodynamicznych oraz numerycznych w procesie niskociśnieniowego natryskiwania na zimno. Badania rozpoczęto od pomiaru natężenia przepływu gazu roboczego na wyjściu z palnika. Następnie w wyniku obliczeń wyznaczono parametry termodynamiczne panujące w różnych częściach dyszy de Lavala. Pozwoliło to wyznaczyć prędkość oraz temperaturę pojedynczej cząstki o średnicy $20 \mu \mathrm{m}$ na wyjściu z dyszy. Otrzymane wyniki wprowadzono do programu numerycznego, gdzie przeprowadzono obliczenia osadzania sferycznej cząstki stopu cyny Sn97Cu3 na płaskim podłożu aluminiowym. Wyniki zestawiono i porównano dla wszystkich badanych nastaw urządzenia. W celu weryfikacji obliczeń przeprowadzono eksperyment, w którym wykorzystano zadane parametry, dla których naniesiono po jednym ściegu warstwy. Przy użyciu elektronowego mikroskopu skaningowego znaleziono pojedynczo osadzone ziarna i porównano je z wynikami numerycznymi pod względem odkształcenia podczas zderzenia z podłożem.
Abstract

The paper describes a possibility of thermodynamic and numerical computations application in Cold Spray process. The research began with flow rate measurements of working gas by rotameter at the end of the torch. Next by a huge range of calculations thermodynamic parameters in de Laval nozzle were determined. Further calculations gave a possibility to determine velocity and temperature of a single particle $20 \mu \mathrm{m}$ in diameter. Obtained results were imported to computer program, where numerical computations of spherical tin alloy (Sn97Cu3) particle deposition on flat aluminum substrate were performed. Numerical results were compared for every given parameters. Finally, several experiments were performed, where in each sample of coating one run was made. Scanning electron microscope was used to find one deposited particle in each run which were compared with numerical results in regard to plastic strain during collision with the substrate.

\section{Wstęp}

Metoda natryskiwania na zimno (cold spray) jest najnowsza spośród metod natryskiwania termicznego. Zasadniczą różnicą między nią, a pozostałymi metodami termicznymi jest brak wysokiej temperatury w procesie, chociaż wymaga ona zapewnienia wysokiej energii

Mgr inż. Marcin Winnicki, mgr inż. Aleksandra Małachowska, prof. dr hab. inż. Andrzej Ambroziak - Politechnika Wrocławska. ziaren proszku do uzyskania połączenia. Kluczowymi parametrami pozostają temperatura i prędkość. Temperatura nadawana jest gazowi roboczemu na początku procesu. Dzięki zastosowaniu dyszy o specjalnym kształcie, konwergentno-dywergentnym (tzw. dyszy de Lavala), rozprężający się gaz osiąga prędkość naddźwiękową. Wprowadzony do dyszy proszek przejmuje od gazu temperaturę i wysoką prędkość.

W zależności od zastosowanej odmiany, proszek może być wprowadzony osiowo w części zbieżnej dyszy (metoda wysokociśnieniowa, high pressure cold spray - HPCS) lub promieniowo w części rozbieżnej, tuż za przewężeniem (metoda niskociśnieniowa, 


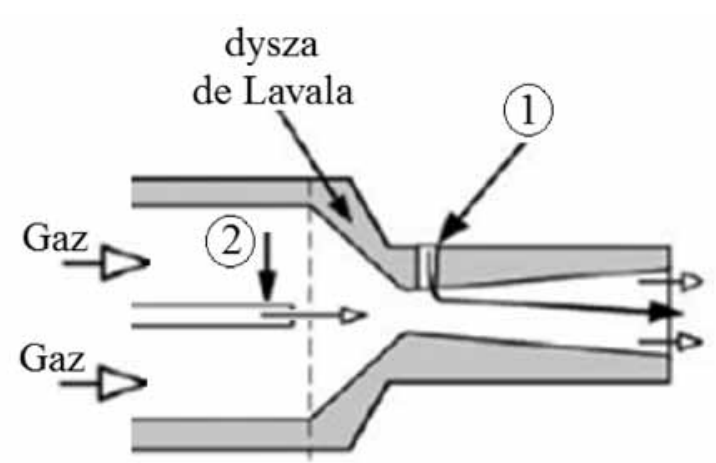

Rys. 1. Miejsca wprowadzenia proszku w dyszy de Lavala w metodzie natryskiwania na zimno: 1 - niskociśnieniowej, 2 - wysokociśnieniowej

Fig. 1. The powder supply placement in de Laval jet for the cold spray: 1 - with low pressure, 2 - with high pressure

low pressure cold spray - LPCS) - rysunek 1. Jak nazwa wskazuje, różnica polega głównie na zastosowanym ciśnieniu, a także miejscu ulokowania nagrzewnicy. W metodzie niskociśnieniowej wartość ciśnienia mieści się w przedziale 0,5 $\div 0,9 \mathrm{MPa}$. Nagrzewnica umieszczona jest wewnątrz palnika i zazwyczaj jej moc nie przekracza $10 \mathrm{~kW}$. Umożliwia to uzyskanie prędkości gazu na wyjściu z dyszy dochodzącej do ok. 700 m/s. Natomiast w metodzie wysokociśnieniowej stosuje się ciśnienie wejściowe powyżej $1 \mathrm{MPa}$, a nagrzewnica stanowi osobny element i ma moc powyżej $30 \mathrm{~kW}$, dzięki czemu podgrzany gaz może osiągnąć prędkość nawet do $1200 \mathrm{~m} / \mathrm{s}$.

\section{Termodynamiczne warunki procesu}

Prędkość ziaren jest krytycznym parametrem procesu, umożliwiającym zbudowanie warstwy metodą natryskiwania na zimno. Ważne jest więc zrozumienie zjawisk termodynamicznych zachodzących w procesie. Głównymi wielkościami mającymi wpływ na przebieg procesu są: temperatura, ciśnienie oraz rodzaj gazu na wejściu, a także kształt dyszy.

Prędkość cząsteczek jest ograniczona jedynie prędkością gazu, dlatego wykorzystanie podwyższonego ciśnienia, długiej dyszy oraz proszku o małej granulacji gwarantują pozyskanie zbliżonych wartości prędkości ziaren proszku i gazu. Ponieważ w metodzie cold spray zastosowano dyszę konwergentno-dywergentną, zakłada się, że przepływ gazu jest izentropowy (adiabatyczny i beztarciowy) oraz jednowymiarowy (równomierny w całym przekroju dyszy), a gaz rozpatrywany jest jako gaz doskonały o stałym cieple właściwym. Przyjmując te upraszczające założenia, można uwzględnić niewielką różnicę między wynikami obliczeniowymi a wartością pomiarową.

Na podstawie przyjętych założeń można stwierdzić, że właściwości gazu zależą od geometrii dyszy, temperatury i ciśnienia. Warunki te dotyczą części zbieżnej

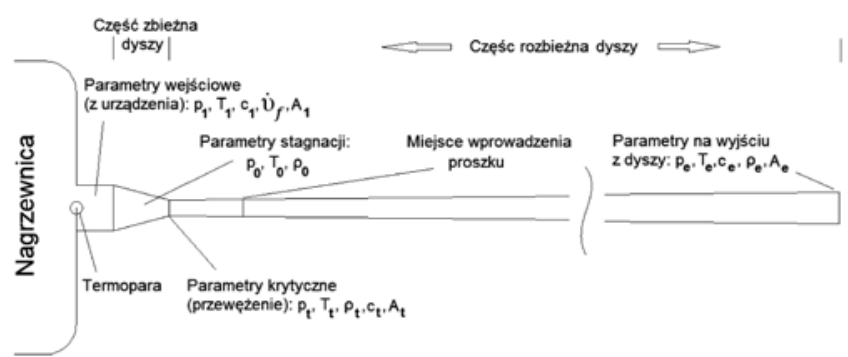

Rys. 2. Schemat dyszy de Lavala z oznaczonymi obszarami pomiarowymi

Fig. 2. De Laval jet scheme with measurement placement

dyszy, tuż przed przewężeniem. Wówczas temperatura i ciśnienie osiągają maksymalne wartości, a prędkość gazu spada do zera (przemiana izentropowa). Dopiero w przewężeniu gaz uzyskuje prędkość, która rośnie podczas rozprężania gazu, kiedy wartość temperatury i ciśnienia znacznie spada. Dlatego proszek musi nabrać prędkości zaraz za przewężeniem dyszy, aby zdążył uzyskać prędkość i temperaturę od gazu. Wbrew nazwie procesu, występuje w nim niewielkie podgrzanie materiału proszkowego, co zwiększa jego plastyczność przy kontakcie z podłożem.

W obliczeniach przyjęto, że temperatura ustawiona na urządzeniu, która jest mierzona przez termoparę przed wejściem do dyszy, stanowi temperaturę początkową $T_{1}$, jednak nie jest ona temperaturą ustalona $T_{0}$. Wynika to $z$ tego, że gaz przemieszcza się na wyjściu z palnika z pewną prędkością $\mathrm{c}_{1}$. Regulacja ciśnienia zaś odpowiada za natężenie przepływu gazu $v_{f}$. Ciśnienie to nie jest równe ciśnieniu $p_{0}$, ponieważ występują straty w przewodach oraz podczas

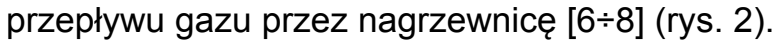

$W$ celu wyznaczenia temperatury $T_{0}$ oraz ciśnienia $\mathrm{p}_{0}$, należy określić rotametrem wartość natężenia przepływu gazu $v_{\mathrm{f}}$ przed wejściem do dyszy, dzięki czemu można wyznaczyć prędkości gazu na wejściu do dyszy $\mathrm{c}_{1}$, a następnie stosując zależności na termodynamiczny przepływ gazu w dyszy, obliczyć prędkość oraz temperaturę cząsteczek $[1 \div 3,6 \div 11]$.

$$
\mathrm{u}_{p}=c_{e} \cdot \sqrt{\frac{C_{D} \cdot A_{p} \cdot \rho_{e} \cdot x}{m_{p}}}
$$

gdzie: $v_{p}$ - prędkość cząstki, m/s; $c_{e}$ - prędkość gazu na wyjściu $z$ dyszy, $\mathrm{m} / \mathrm{s} ; \mathrm{m}_{\mathrm{p}}$ - masa cząstki, g; $\mathrm{A}_{\mathrm{p}}$ - pole przekroju cząstki, $\mathrm{mm}^{2}$; $\rho_{\mathrm{e}}$ - gęstość gazu na wyjściu $z$ dyszy, $\mathrm{kg} / \mathrm{m}^{3} ; \mathrm{x}$ - odległość wyjścia z dyszy od miejsca wprowadzenia proszku (część rozbieżna dyszy), $\mathrm{mm} ; \mathrm{C}_{\mathrm{D}}$ - współczynnik oporu cyny.

Ze wzoru (1) wynika, że kluczowe znaczenie dla prędkości cząsteczki na wyjściu z dyszy, poza prędkością gazu, mają: długość części rozbieżnej dyszy, gęstość gazu oraz masa cząsteczki. Temperaturę cząsteczki na wyjściu z dyszy można wyznaczyć z zależności na prędkość nagrzewania, ponieważ jest ona traktowana jako ciało izotermiczne [9]: 


$$
\frac{d T_{P}}{d t}=\frac{h \cdot A \cdot\left(T_{g}-T_{p 0}\right)}{m_{p} \cdot C_{p p}}
$$

gdzie: $T_{p}$ - temperatura cząstki, $K ; C_{p 0}$ - ciepło właściwe materiału cząstki przy stałym ciśnieniu, $\mathrm{J} /(\mathrm{kg} \cdot \mathrm{K}) ; \mathrm{m}_{\mathrm{p}}$ - masa cząstki, $\mathrm{m}^{3} / \mathrm{kg}$; $\mathrm{A}$ - pole powierzchni zewnętrznej cząstki, $\mathrm{mm}^{2} ; \mathrm{T}_{\mathrm{g}}$ - temperatura gazu na wyjściu $z$ dyszy, $K ; T_{p 0}$ - temperatura proszku przed wprowadzeniem do dyszy, $\mathrm{K} ; \mathrm{h}$ - współczynnik przenikania ciepła gazu $\mathrm{W} /\left(\mathrm{m}^{2} \cdot \mathrm{K}\right)$.

\section{Budowa modelu}

W dyszy, w badaniach skupiono się na obliczeniowym wyznaczeniu wartości prędkości oraz temperatury gazu na wyjściu z dyszy de Lavala, co umożliwiło dalsze wyliczenie prędkości i temperatury pojedynczych ziaren proszku o odpowiedniej wielkości. Otrzymane w ten sposób optymalne wartości zostały wprowadzone do oprogramowania MES - Abaqus/Explicit ver. 6.10, które zawiera dynamiczną symulację 3D uderzenia pojedynczej cząstki cyny o podłoże aluminiowe, przy wykorzystaniu sformułowań Lagrange’a. Do warunków brzegowych procesu należą dwa niezmienne parametry: temperatura początkowa podłoża $\mathrm{T}_{\mathrm{S}}=20^{\circ} \mathrm{C}$ oraz wielkość ziarna $d_{p}=20 \mu \mathrm{m}$. Analizowane próby oraz dobrane $w$ nich parametry zostały przedstawione w tablicy I.

Pomiar natężenia przepływu gazu rotametrem jest wiarygodny dla ciśnienia atmosferycznego wynoszącego 1,013 barów oraz temperatury $15^{\circ} \mathrm{C}$. Każda zmiana mierzonego czynnika wymaga stosowania współczynnika korekcyjnego, dlatego w celu określenia dokład-

Tablica I. Dobór parametrów modelu Table I. Parameters selection

\begin{tabular}{|c|c|c|c|c|}
\hline \multirow{2}{*}{$\begin{array}{c}\mathrm{Nr} \\
\text { próby }\end{array}$} & \multicolumn{2}{|c|}{ Nastawy urządzenia } & \multirow{2}{*}{$\begin{array}{c}\text { Zmierzone natę- } \\
\text { żenie przepływu } \\
\dot{v}_{\mathrm{fo}}, \mathrm{m}^{3} / \mathrm{h}\end{array}$} & \multirow{2}{*}{$\begin{array}{l}\text { Obliczone natę- } \\
\text { żenie przepływu } \\
\dot{v}_{\mathrm{fo}}, \mathrm{m}^{3} / \mathrm{h}\end{array}$} \\
\hline & $\begin{array}{c}\text { Ciśnienie } \\
\mathrm{p}_{1}, \mathrm{MPa}\end{array}$ & $\begin{array}{c}\text { Temperatura } \\
\mathrm{T}_{1},{ }^{\circ} \mathrm{C}\end{array}$ & & \\
\hline 1 & 0,5 & 20 & 33,8 & 38,3 \\
\hline 2 & 0,5 & 200 & 33,8 & 38,3 \\
\hline 3 & 0,6 & 20 & 38,6 & 43,1 \\
\hline 4 & 0,6 & 200 & 38,6 & 43,1 \\
\hline 5 & 0,7 & 20 & 43,2 & 47,8 \\
\hline 6 & 0,7 & 200 & 43,2 & 47,8 \\
\hline
\end{tabular}

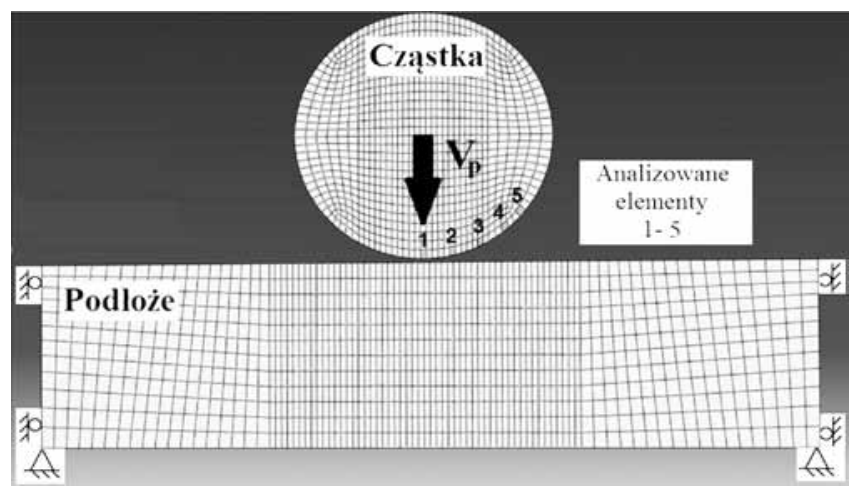

Rys. 3. Analizowany model (cząstka uderza w podłoże) z widokiem w przekroju

Fig. 3. Scheme of analysed model (particle impact on substrate) in the cross-section

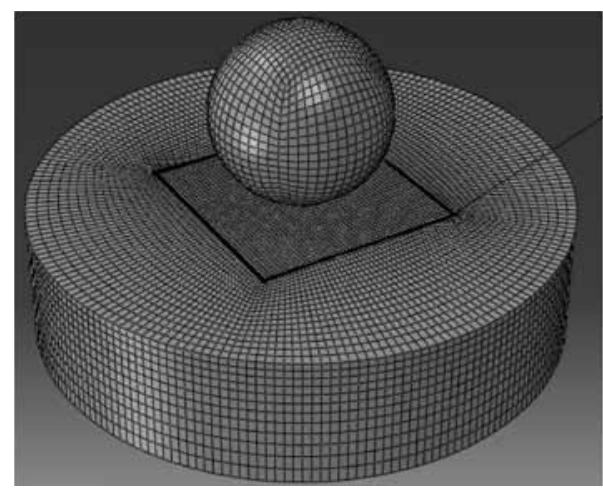

Obszar kontaktu z zagęszczoną siatką

Rys. 4. Widok 3D modelu

Fig. 4. 3D model view

nych wartości panujących w dyszy posłużono się następującą zależnością:

$$
\dot{\mathrm{v}}_{f}=\dot{\mathrm{v}}_{f 0} \cdot \sqrt{\frac{\rho_{1} \cdot T_{1} \cdot p_{2}}{\rho_{2} \cdot T_{2} \cdot p_{1}}}
$$

gdzie: $\dot{v}_{f}-$ natężenie przepływu gazu, $\mathrm{m}^{3} / \mathrm{min} ; \dot{v}_{\text {f0 }}-$ pomiarowe natężenia przepływu gazu $\mathrm{m}^{3} / \mathrm{min} ; \rho_{1}$ - gęstość względna powietrza, $\mathrm{kg} / \mathrm{m}^{3} ; \rho_{2}$ - gęstość względna mierzonego gazu, $\mathrm{kg} / \mathrm{m}^{3} ; \mathrm{T}_{1}$ - standardowa temperatura kalibracji rotametru, $\mathrm{K} ; \mathrm{T}_{2}$ - aktualna temperatura absolutna mierzonego gazu, $\mathrm{K} ; \mathrm{p}_{1}$ - ciśnienie atmosferyczne MPa; $\mathrm{p}_{2}-$ aktualne ciśnienie absolutne mierzonego gazu, MPa.

Przeprowadzone zgodnie ze wzorem (3) obliczenia wykazały, że wzrost temperatury nie spowodował wzrostu natężenia przepływu gazu, co jest związane z równomiernym spadkiem gęstości gazu przy odpowiednim wzroście temperatury. Na rysunku 3 przedstawiono schemat modelu z naniesionymi warunkami brzegowymi oraz wskazano elementy cząstki, które będą podlegały szczegółowej analizie. Na rysunku 4 pokazano model 3D z oznaczonym obszarem kontaktu.

Natryskiwane ziarna mają tak dużą energię, że podczas ich kontaktu z podłożem dochodzi do przerwania cienkiej warstwy tlenków, co umożliwia połączenie czystych materiałów. Potwierdza to teorię, że wymagana jest minimalna prędkość krytyczna $v_{c}$, dająca odpowiednią energię kinetyczną $E_{k}$ podczas kontaktu proszku z podłożem, w celu jego osadzenia [1]. Energia kinetyczna $E_{k}$ cząsteczki o masie $m_{p}$ i prędkości $v_{p} \geq v_{c}$ będzie miała wartość:

$$
E_{k}=\frac{m_{p} \cdot v_{p}^{2}}{2}
$$

Uzyskana maksymalna energia kinetyczna $E_{k}$ w chwili zetknięcia zamieniana jest na kilka innych wielkości, umożliwiających uzyskanie połączenia, do których należą: energia odkształcenia plastycznego $E_{p}$, energia odkształcenia sprężystego $E_{e}$, energia wykorzystana na pokonanie tarcia $E_{f}$ oraz energia cieplna Q:

$$
E_{k}=E_{p}+E_{e}+E_{f}+Q
$$


Podczas zderzenia cząstki z podłożem dochodzi do ścinania adiabatycznego, które jest zjawiskiem odgrywającym główną rolę podczas łączenia ziaren z podłożem i między sobą. Uwzględniając dodatkowo fluktuację naprężenia, odkształcenia, temperatury, jak również mikrostruktury, lokalnie dochodzi do płynięcia plastycznego. W związku z tym do obliczeń numerycznych metodą elementów skończonych trzeba dobrać odpowiedni model materiałowy. W przeprowadzonych symulacjach spośród wielu dostępnych modeli wybrano model Johnsona-Cooka, który umożliwia dokładne otworzenie procesu odkształcenia plastycznego materiału, ponieważ uwzględnia umocnienie wywołane zgniotem, jego prędkość oraz termiczne zmiękczenie materiału $[4,5]$. Model ten jest opisany wzorem (6), dane materiałowe niezbędne do jego stosowania podano $w$ tablicy II.

$$
\sigma=\left[A+B \cdot \varepsilon^{n}\right] \cdot\left[1+C \cdot \ln \dot{\varepsilon}^{*}\right] \cdot\left[1-T^{* m}\right]
$$

gdzie: $\sigma$ - ekwiwalent naprężenia plastycznego płynięcia Hubera von Misesa, $\mathrm{MPa} ; \varepsilon$ - odkształcenie plastyczne, $\varepsilon^{*}-$ równoważna prędkość odkształcenia; $A, B, C, n, m$ - stałe materiałowe podane $w$ tabl. II; $T^{*}$ - temperatura homologiczna:

$$
T^{*}=\frac{T-T_{\text {ref }}}{T_{m}-T_{\text {ref }}}
$$

gdzie: $T$ - temperatura bieżąca, $K ; T_{m}-$ temperatura topnienia materiału, $\mathrm{K} ; \mathrm{T}_{\text {ref }}$ - temperatura brzegowa; $\mathrm{K}$, powyżej której występuje zmiękczenie materiału na skutek wpływu ciepła.

Tablica II. Dane materiałowe wykorzystane w modelu [15]

\begin{tabular}{|c|c|}
\hline Parametr & Wartość \\
\hline Gęstość, $\mathrm{kg} / \mathrm{m}^{3}$ & 7360 \\
\hline Moduł Younga, GPa & 45 \\
\hline Liczba Poissona & 0,36 \\
\hline Współczynnik rozszerzalności cieplnej, $1 /{ }^{\circ} \mathrm{C}$ & $2,27 \mathrm{E}-05$ \\
\hline Ciepło właściwe, $\mathrm{J} / \mathrm{kg} \cdot \mathrm{K}$ & 220 \\
\hline Współczynnik przewodności cieplnej, $\mathrm{W} / \mathrm{m} \cdot \mathrm{K}$ & 66,6 \\
\hline \multicolumn{2}{|l|}{ Stałe Johnsona-Cooka } \\
\hline A - granica plastyczności, MPa & 29 \\
\hline $\mathrm{B}$ - moduł twardości, MPa & 243 \\
\hline C - stała umocnienia się materiału & 0,0956 \\
\hline $\mathrm{n}$ - wykładnik utwardzenia & 0,703 \\
\hline m - stała & 0,8 \\
\hline $\mathrm{T}_{\text {melt }}-$ temperatura topnienia, ${ }^{\circ} \mathrm{C}$ & 228 \\
\hline $\mathrm{T}_{\text {ref }}-$ temperatura brzegowa, ${ }^{\circ} \mathrm{C}$ & 25 \\
\hline$\varepsilon_{0 \text { ref }}-$ referencyjna prędkość odkształcenia & 1 \\
\hline
\end{tabular}

Table. II. Material properties used for model [15]

\section{Wyniki i dyskusja}

W przeprowadzonych badaniach skupiono się na naniesieniu pojedynczych ziaren cyny na gładkie, wytrawione podłoże aluminiowe, w celu uwidocznienia mechanizmu połączenia cząstek z podłożem. Do naniesienia proszku na podłoże wykorzystano niskociśnieniowe urządzenie do natryskiwania na zimno DYMET 413. W badaniach stosowano proszek stopu cyny Sn97Cu3, otrzymany metoda atomizacji w azocie, o kształcie sferycznym i granulacji poniżej $71 \mu \mathrm{m}$ (rys. 5). Wartość natężenia przepływu gazu została zmierzona dla poszczególnych ustawień parametrów urządzenia podanych w tablicy I.

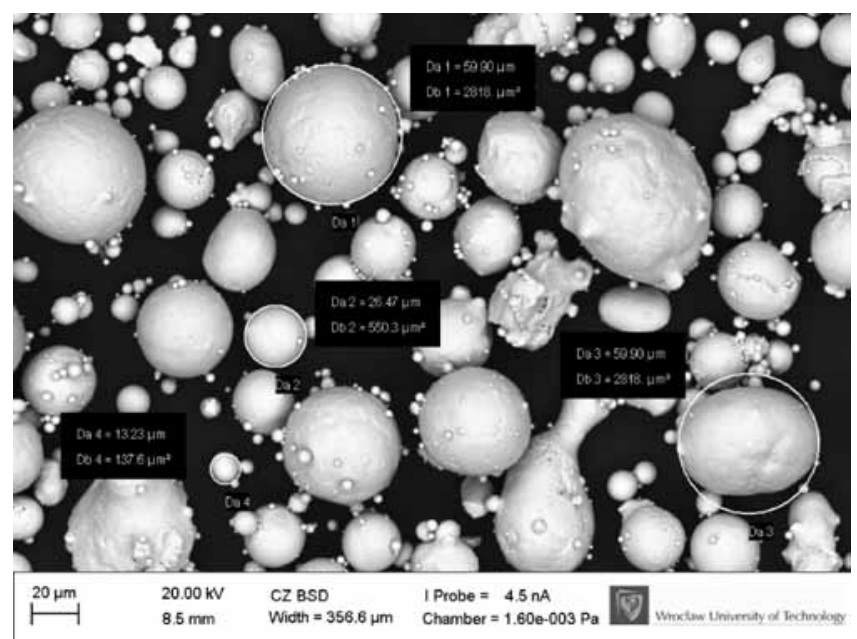

Rys. 5. SEM proszku stopu Sn97Cu3 o granulacji $\leq 71 \mu \mathrm{m}$ zastosowanego w badaniach

Fig. 5. SEM view of Sn97Cu3 alloy powder with particle size $\leq 71$ $\mu \mathrm{m}$, used in tests

Otrzymane wyniki obliczeń termodynamicznych zostały zawarte $w$ tablicy III. Analizując otrzymane wartości gęstości w przewężeniu można zauważyć, że wraz ze wzrostem temperatury następuje jej spadek. Natomiast ze wzrostem ciśnienia następuje wzrost gęstości. Obie sytuacje są zgodne $z$ zasadą zachowania gazu doskonałego. Warto zwrócić uwagę na różnicę między gęstością w przewężeniu oraz na wyjściu z dyszy. Wynika to z rozprężania gazu w części dywergentnej, gdzie następuje nagły spadek ciśnienia do wartości ok. 5-krotnie mniejszej od wartości ciśnienia atmosferycznego. Mimo że temperatura jest taka sama, to jednak wzrost ciśnienia dla poszczególnych prób, a co za tym idzie - wzrost gęstości, prowadzą do wzrostu prędkości cząsteczek. Jeśli zaś chodzi o temperaturę cząsteczek, wzrasta ona zaraz po wprowadzeniu proszku do dyszy i nie spada przed jej opuszczeniem.

Przy ciśnieniu 7 barów i temperaturze $200^{\circ} \mathrm{C}$, dla cząstki $20 \mu \mathrm{m}$ otrzymano prędkość powyżej $600 \mathrm{~m} / \mathrm{s}$. Dla mniejszych cząsteczek potrzebna jest wyższa prędkość do uzyskania połączenia, która jest zbliżona do prędkości gazu. Prędkość ta zależy od temperatury wejściowej gazu, która dla badanych dwóch wartości wynosiła odpowiednio ok. $650 \mathrm{~m} / \mathrm{s}$ dla gazu 
Tablica III. Wyniki obliczeń termodynamicznych

Table III. Thermodynamic calculation results

\begin{tabular}{|c|c|c|c|c|c|c|c|c|}
\hline \multirow[b]{2}{*}{$\begin{array}{c}\mathrm{Nr} \\
\text { próby }\end{array}$} & \multicolumn{8}{|c|}{ Analizowana wielkość } \\
\hline & $\begin{array}{l}\text { Ciśnienie } \\
\mathrm{p} 1, \mathrm{MPa}\end{array}$ & $\begin{array}{c}\text { Temperatura } \\
\mathrm{T} 1,{ }^{\circ} \mathrm{C}\end{array}$ & $\begin{array}{c}\text { Zmierzone natę- } \\
\text { żenie przepływu } \\
\qquad \mathrm{u}_{\mathrm{f}}, \mathrm{m}^{3} / \mathrm{h}\end{array}$ & $\begin{array}{l}\text { Prędkość gazu na } \\
\text { wejściu do dyszy } \\
\qquad c_{1} \mathrm{~m} / \mathrm{s}\end{array}$ & $\begin{array}{c}\text { Prędkość gazu na } \\
\text { wyjściu z dyszy } \\
\text { ce } \mathrm{m} / \mathrm{s}\end{array}$ & $\begin{array}{c}\text { Gęstość gazu na } \\
\text { wyjściu z dyszy pe } \\
\mathrm{kg} / \mathrm{m}^{3}\end{array}$ & $\begin{array}{c}\text { Prędkość } \\
\text { cząstki up } \\
\text { m/s }\end{array}$ & $\begin{array}{l}\text { Temp. } \\
\text { cząstki } \\
\mathrm{Tp},{ }^{\circ} \mathrm{C}\end{array}$ \\
\hline 1 & 0,5 & 20 & 38,3 & 248 & 643 & 0,61 & 473 & 12 \\
\hline 2 & 0,5 & 200 & 38,3 & 248 & 802 & 0,35 & 501 & 62 \\
\hline 3 & 0,6 & 20 & 43,1 & 279 & 651 & 0,78 & 519 & 15 \\
\hline 4 & 0,6 & 200 & 43,1 & 279 & 808 & 0,43 & 537 & 63 \\
\hline 5 & 0,7 & 20 & 47,8 & 309 & 659 & 0,97 & 577 & 18 \\
\hline 6 & 0,7 & 200 & 47,8 & 309 & 815 & 0,53 & 611 & 59 \\
\hline
\end{tabular}

o temp. $20^{\circ} \mathrm{C}$ na wejściu i ok. $800 \mathrm{~m} / \mathrm{s}$ dla temp. $200^{\circ} \mathrm{C}$ (wahania po uwzględnieniu wszystkich prób mieszczą się w przedziale $\pm 20 \mathrm{~m} / \mathrm{s}$ dla obu przypadków). Ciśnienie ma jednak znaczny wpływ na prędkość cząsteczek. Wraz ze spadkiem ciśnienia w części dywergentnej maleje gęstość gazu, a jak wynika ze wzoru (1), gazu ma to znaczny wpływ na prędkość cząsteczki.
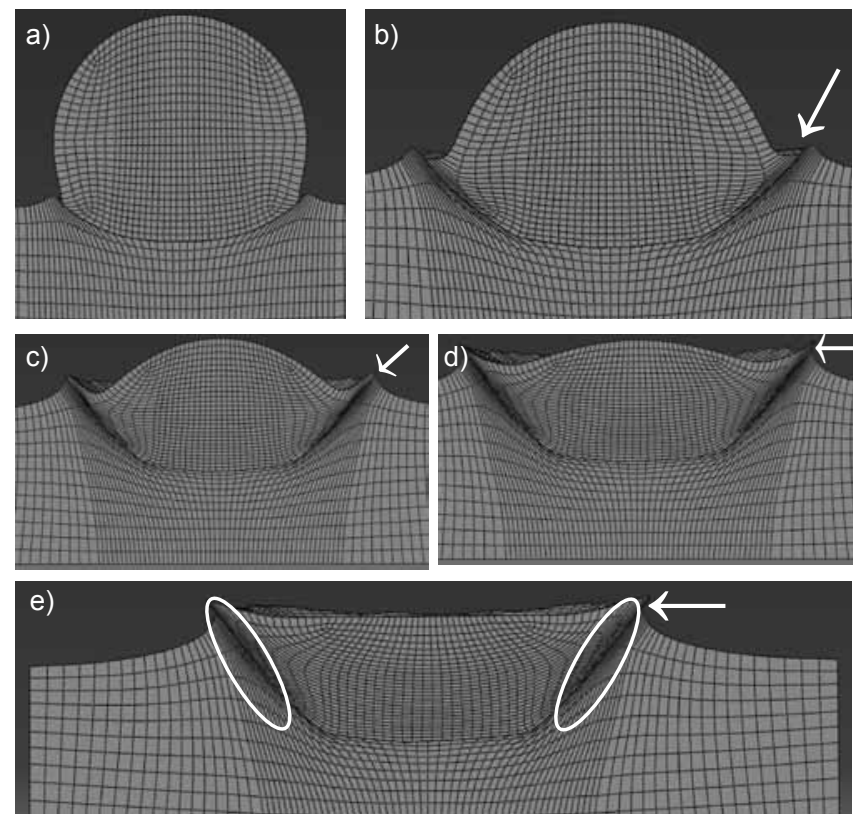

Rys. 6. Kształt cząstki w różnych etapach procesu, od chwili kontaktu po: a) $10 \mathrm{~ns}$, b) $20 \mathrm{~ns}$, c) $30 \mathrm{~ns}$, d) $40 \mathrm{~ns}$, e) $55 \mathrm{~ns}$; Strzałką oznaczono powstającą wypływkę materiału; parametry: $v_{\mathrm{p}}=473 \mathrm{~m} / \mathrm{s}$, $\mathrm{T}_{\mathrm{p}}=12^{\circ} \mathrm{C}$

Fig. 6. The shape of the particles in various stages of the process, from the moment of contact: a) $10 \mathrm{~ns}$, b) $20 \mathrm{~ns}$, c) $30 \mathrm{~ns}$, d) $40 \mathrm{~ns}$ e) $55 \mathrm{~ns}$; Arrow indicate the material burr; Parameters: $v_{\mathrm{p}}=473 \mathrm{~m} / \mathrm{s}$, $\mathrm{T}_{\mathrm{p}}=12^{\circ} \mathrm{C}$
Otrzymane wartości prędkości oraz ciśnienia zostały wykorzystane $w$ budowanym modelu osadzania cząstki sferycznej cyny na podłożu aluminiowym. Na rysunku 6 przedstawiono kształt cząstki w różnych etapach procesu (po 10 $\div 55 \mathrm{~ns}$ ) przy zadanych parametrach z próby 1 . Strzałką oznaczono powstającą wypływkę. Cyna jest materiałem miękkim, ciągliwym, o stosunkowo dużej gęstości, w związku z czym wypływka jest wyraźna. Należy zwrócić szczególną uwagę na siatkę, którą celowo pozostawiono. W obszarze, gdzie powstaje wypływka, dochodzi do największych odkształceń, na co wskazują intensywnie odkształcone elementy siatki (rys. 6e). W obszarze tym dochodzi też do intensywnego nagrzewania materiału (zarówno ziarna, jak i podłoża) w wyniku tarcia płynącego materiału cząstki o podłoże.

W celu zbadania rozwoju obszarów ścinania adiabatycznego w obszarze kontaktu cząstki i podłoża monitorowano kilka wybranych elementów siatki (rys. 4), a następnie przedstawiono wzrost temperatury, odkształcenia plastycznego, prędkości odkształcenia oraz naprężeń normalnych w tych obszarach. Otrzymane wyniki obliczeń obrazujące wartości dla całego modelu w poszczególnych próbach zestawiono w tablicy IV, w której zawarto dodatkowo jeden parametr, tzw. współczynnik spłaszczenia, który oddaje zmianę wysokości ziarna względem pierwotnej średnicy. Można go wyznaczyć z następującej zależności [4]:

$$
R_{p}=\frac{D_{p}-h_{p}}{D_{p}} \cdot 100
$$

gdzie: $R_{p}$ - współczynnik spłaszczenia, \%; $D_{p}$ - średnica cząstki, $\mu \mathrm{m}$; $\mathrm{h}_{\mathrm{p}}$ - wysokość w osi cząstki po deformacji, $\mu \mathrm{m}$.

Tablica IV. Maksymalne wartości kluczowych parametrów cząstki po procesie natryskiwania Table IV. Maximum values of key parameters of particie after spraying process

\begin{tabular}{|c|c|c|c|c|c|c|c|}
\hline \multirow{2}{*}{$\begin{array}{c}\mathrm{Nr} \\
\text { próby }\end{array}$} & \multicolumn{2}{|c|}{ Nastawy urządzenia } & \multicolumn{2}{|c|}{ Dane wejściowe } & \multicolumn{3}{c|}{ Dane wyjściowe cząstki } \\
\cline { 2 - 8 } & Temp. $\mathrm{T}_{1},{ }^{\circ} \mathrm{C}$ & $\begin{array}{c}\text { Ciśnienie } \\
\mathrm{p}_{1}, \text { bar }\end{array}$ & $\begin{array}{c}\text { Temp. } \\
\text { cząstki T }_{\mathrm{p}}{ }^{\circ} \mathrm{C}\end{array}$ & $\begin{array}{c}\text { Prędkośćc } \\
\text { cząstki } v_{\mathrm{p}}, \mathrm{m} / \mathrm{s}\end{array}$ & $\begin{array}{c}\text { Maks. } \\
\text { temperatura, }{ }^{\circ} \mathrm{C}\end{array}$ & $\begin{array}{c}\text { Wysokość cząstki po } \\
\text { deformacji } \mathrm{h}_{\mathrm{p}}, \mu \mathrm{m}\end{array}$ & $\begin{array}{c}\text { Współczynnik } \\
\text { spłaszczenia, \% }\end{array}$ \\
\hline 1 & 20 & 5 & 12 & 473 & $225(44 \mathrm{~ns})$ & 9,3 & 53,5 \\
\hline 2 & 200 & 5 & 62 & 501 & $226(55 \mathrm{~ns})$ & 8,1 & 59,5 \\
\hline 3 & 20 & 6 & 15 & 519 & $226(46 \mathrm{~ns})$ & 9,4 & 53 \\
\hline 4 & 200 & 6 & 63 & 537 & $226(55 \mathrm{~ns})$ & 8,4 & 58 \\
\hline 5 & 20 & 7 & 18 & 577 & $241(46 \mathrm{~ns})$ & 9,6 & 54 \\
\hline 6 & 200 & 7 & 59 & 611 & $239(38 \mathrm{~ns})$ & 9,2 & 52 \\
\hline
\end{tabular}


$\mathrm{Na}$ rysunku 7 przedstawiono wykresy zmiany wartości temperatury cząstki $w$ funkcji czasu, dla wybranych elementów modelu w poszczególnych próbach. Należy zwrócić uwagę, że począwszy od wykresu przedstawionego na rysunku 7b, występuje opóźnienie we wzroście temperatury. Wynika to $z$ tego, że dane elementy znajdują się w pewnej odległości od osi cząstki, później podlegają kontaktowi z podłożem i odkształceniu, natomiast element $\mathrm{nr} 1$ (rys. 7a) leży w linii osi. Pierwsze dwa wykresy (rys. $7 a, b)$ uwidoczniają wyraźną różnicę między próbami wykonanymi $z$,zimnym” gazem o temperaturze $20^{\circ} \mathrm{C}$ (próby $1,3,5$ ) a próbami, gdzie gaz został podgrzany do $200^{\circ} \mathrm{C}$ (próby $2,4,6$ ). Różnica ta zaciera się dla kolejnych elementów (rys. $7 \mathrm{c} \div \mathrm{e}$ ), gdyż są one poddawane coraz większym odkształceniom. Dlatego dla elementu $\mathrm{nr} 5$, który jest najbardziej oddalony od osi cząstki, w wyniku dużej energii tarcia dochodzi do bardzo szybkiego nagrzewania się obszaru (linie wzrostowe na rysunku 7e są niemal pionowe). $\mathrm{Na}$ skutek tego w końcowym etapie procesu temperatura we wszystkich próbach dla elementu nr 5 jest bardzo zbliżona (rys. 7e).

Jak wynika z tablicy IV, maksymalna wartość temperatury procesu oscyluje $w$ zakresie $230 \div 240^{\circ} \mathrm{C}$ niezależnie od tego, czy gaz na wejściu do dyszy miał temperaturę $20 \mathrm{czy} 200^{\circ} \mathrm{C}$. Świadczy to o tym, że proszek cyny podlega powierzchniowym, lokalnym nadtopieniom, co może się przyczynić do połączenia metalurgicznego cyny $z$ podłożem aluminiowym.

Kluczowym parametrem w procesie natryskiwania na zimno jest temperatura. Dzięki jej niskim wartościom możliwe jest wykonywanie warstw $z$ materiałów utleniających się $w$ podwyższonych temperaturach, a także pokrywanie materiałów o niskiej temperaturze topnienia dlatego przeprowadzono szczegółową analizę rozkładu pola temperatur dla wszystkich 6 prób po ostatecznym osadzeniu ziarna w 55 ns (rys. 8). Porównując rysunki, można zauważyć zmianę kształtu ziarna wywołaną wzrostem energii procesu, który został wywołany wzrostem temperatury oraz prędkości ziarna. Zmianie tej towarzyszy większa głębokość i średnica krateru oraz dłuższa wypływka. Jest to o tyle niekorzystne, że do zbudowania warstwy potrzebna jest większa ilość materiału, co automatycznie zmniejsza wydajność procesu. Według [12,14] możliwe jest osadzenie ziaren proszku cyny już przy prędkości wynoszącej ok. $200 \mathrm{~m} / \mathrm{s}$, ponieważ wartość prędkości krytycznej wyznaczono na $180 \mathrm{~m} / \mathrm{s}$. Mniejsza prędkość umożliwiłaby zapewne otrzymanie osadzonej cząstki o mniejszym współczynniku spłaszczenia, co zwiększyłoby wydajność procesu. Jednak nieznana jest wartość przyczepności warstwy otrzymana przy tak niskiej prędkości w porównaniu do wartości przyjętych w obecnych badaniach. Będzie to celem przyszłych analiz.

Należy zwrócić uwagę, że większy wpływ na odkształcenie ziarna ma wzrost temperatury niż wzrost
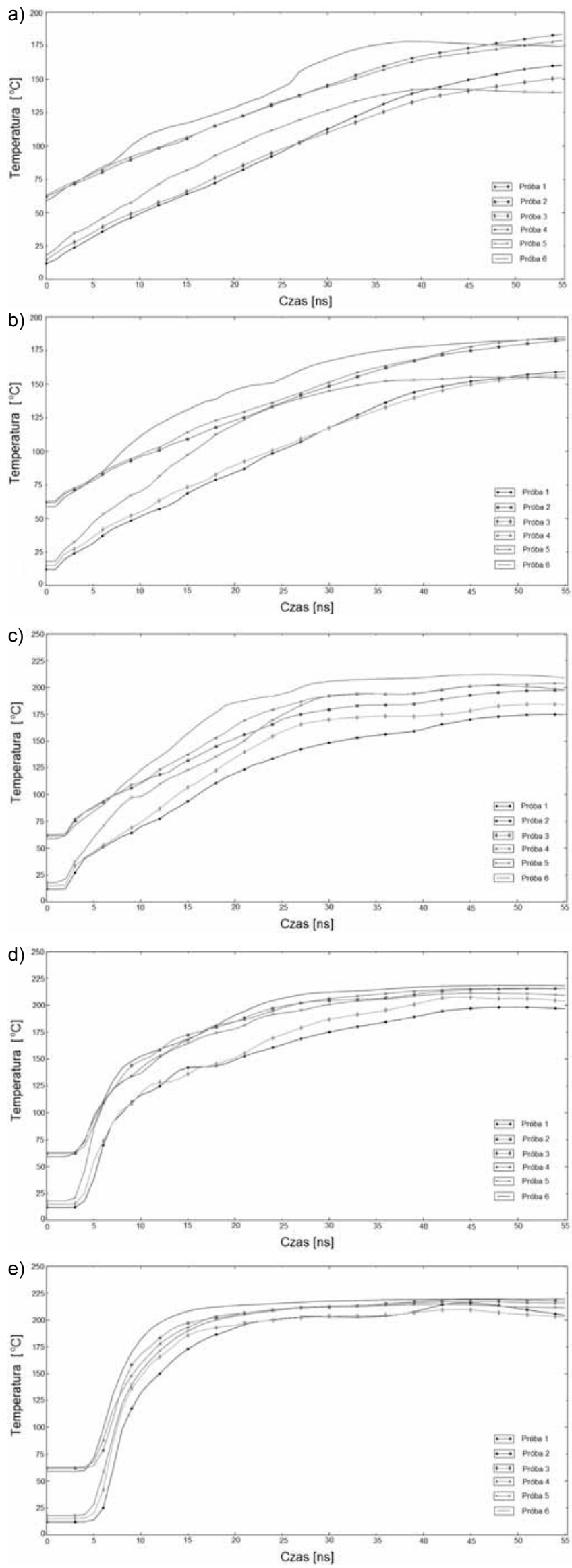

Rys. 7. Temperatura w funkcji czasu dla wszystkich prób w poszczególnych elementach: a) 1, b) 2, c) 3, d) 4, e) 5

Fig. 7. The temperature curves as a function of time for all the samples in the different elements: a) 1, b) 2, c) 3, d) 4, e) 5 
prędkości, co widać po większym współczynniku spłaszczenia dla prób, gdzie temperatura gazu wyniosła $200^{\circ} \mathrm{C}$ (rys. 8 b, d, f). Poza tym wyższa temperatura ziarna na początku procesu prowadzi do powstania wyższej temperatury na większym obszarze.

Przeprowadzone obliczenia wykazały, że energia kinetyczna procesu ma wartość znacznie niższą od energii niezbędnej do stopienia materiału. Tarcie powierzchniowe obszarów poddanych największej deformacji (tam, gdzie powstała wypływka) doprowadziło do wyższych wartości temperatury, sięgających ok. $220^{\circ} \mathrm{C}$ w powstałej wypływce, niezależnie od tego, czy temperatura gazu na wejściu miała 20, czy $200^{\circ} \mathrm{C}$. Można stwierdzić, że nadtopiony obwodowo materiał wypływki, będąc w stanie wysokiej plastyczności, podda się odkształceniu przy naporze kolejnej

a)

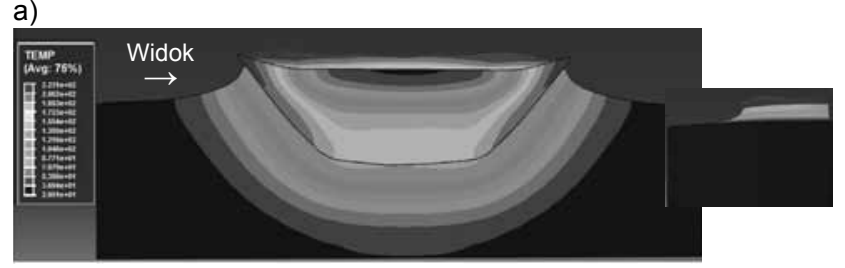

b)

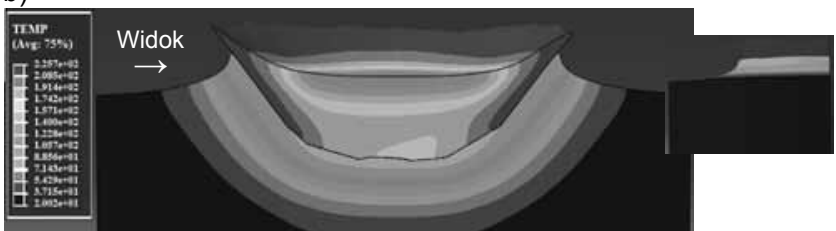

c)

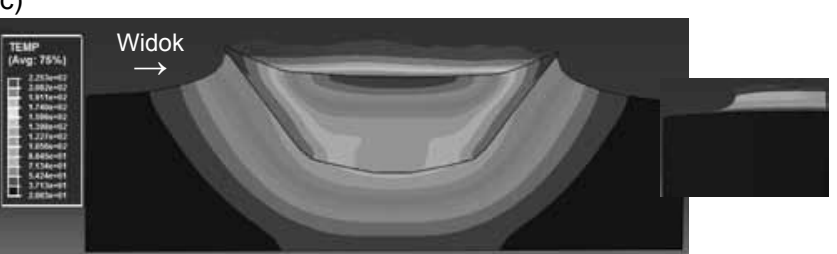

d)

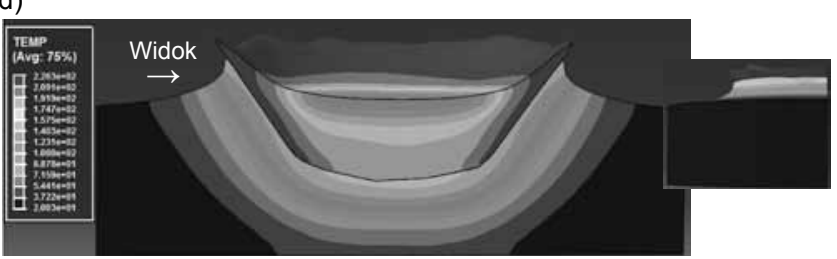

e)

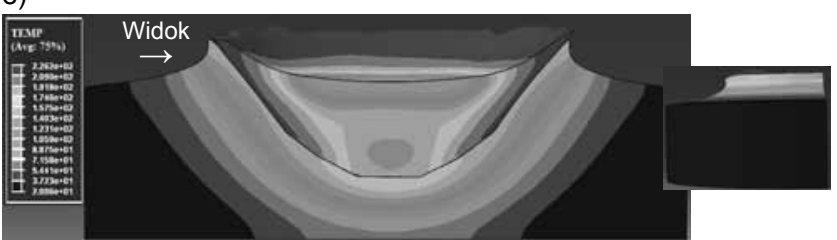

f)

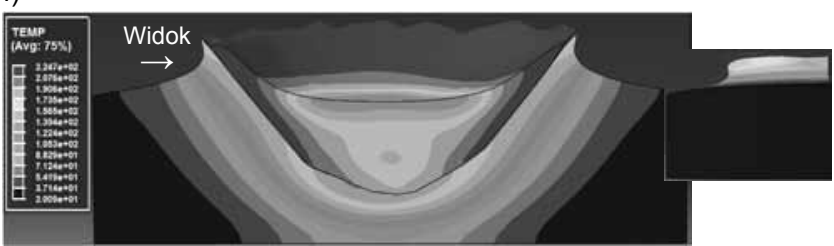

Rys. 8. Pola temperatury po osadzeniu ziarna (55 ns) w poszczególnych próbach: a) 1, b) 2, c) 3, d) 4, e) 5, f) 6

Fig. 8. The temperature field after particle deposition (55 ns) in samples: a) 1, b) 2 , c) 3 , d) 4 , e) 5, f) 6

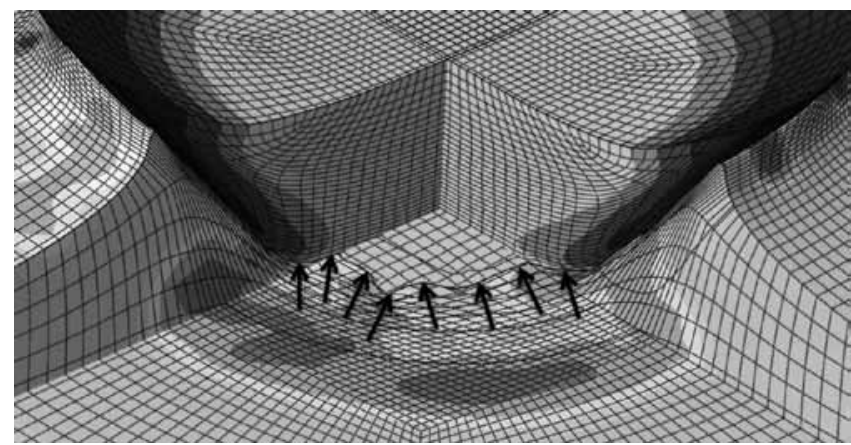

Rys. 9. Nieregularna linia przekroju świadcząca o zakotwiczeniu cząsteczki

Fig. 9. Irregular line of cross-section as the results of particle deposition

cząsteczki i wypełni równomiernie obszar kontaktu między osadzonymi ziarnami. Ponadto lokalne nadtopienia stopu cyny w strefie styku z podłożem mogą doprowadzić do powstania lokalnych punktów sczepnych i w konsekwencji do połączenia metalurgicznego materiału cząstki i podłoża.

Dla każdej z prób odkryto nieregularną linię połączenia ziarna z podłożem, świadczącą o zakotwiczeniu cząstki do podłoża (rys. 9). W pozostałych metodach natryskiwania cieplnego tego typu zakotwiczenia wymagają wcześniejszego przygotowania powierzchni (aktywacji), dochodzi wtedy do powstania punktów sczepnych, jednak stanowią one zaledwie $20 \div 30 \%$ strefy kontaktu [13]. Jak można zaobserwować na przedstawionych zdjęciach, dla metody natryskiwania na zimno w analizach numerycznych wykorzystano gładkie podłoże. Energia w tym procesie jest na tyle duża, że wystarcza na odkształcenia podłoża oraz trwałe zakotwiczenie w nim ziaren proszku. Wynika to z tego, że pierwsze ziarna proszku docierające do powierzchni powodują jej kraterowanie (aktywację).

W części eksperymentalnej badań naniesiono dla każdej próby po jednym ściegu warstwy, które dalej podlegały analizie na mikroskopie skaningowym. Skupiono się na obszarach zewnętrznych, obwodowych warstwy, gdzie odnaleziono pojedyncze osadzone ziarna, w celu porównania ich kształtu z kształtem cząstek uzyskanych w modelu. Widok próbki przed natryskiwaniem przedstawiono na rysunku 10a, natomiast obszar z pogranicza warstwy na rysunku $10 \mathrm{~b}$. Należy podkreślić, że w tym obszarze ziarna proszku przebiegają w strumieniu pod pewnym kątem, ponieważ są najdalej wysunięte od osi strumienia. Uderzający w ten sposób o powierzchnię strumień tworzy falę uderzeniową,
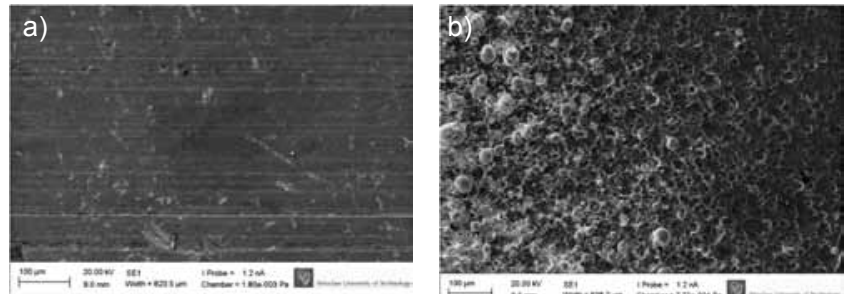

Rys. 10. SEM podłoża przed (a) i po (b) natryskiwaniu

Fig. 10. SEM view of substrate before (a) and after (b) spraying 
która wypycha część ziaren na bok, skutkiem czego dochodzi tylko do kraterowania powierzchni i odbijania zniekształconych ziaren proszku w postaci ubytku. Obszar ten stanowi początek budowanej warstwy.

Zaobserwowano, że przy pierwszej próbie $\left(p_{1}=5\right.$ barw; $\mathrm{T}_{1}=20^{\circ} \mathrm{C}$ ) doszło przede wszystkim do kraterowania powierzchni. W całym obszarze warstwy niewiele ziaren zostało osadzonych. Wynika to z niskich wartości parametrów procesu oraz zastosowania tylko jednego przejścia. Kolejne próby umożliwiły uzyskanie spójnej warstwy we wszystkich przypadkach (rys. 11a $\div$ c). Świadczy to o konieczności uzyskania odpowiedniej energii procesu przez zwiększenie temperatury bądź ciśnienia gazu. Można zaobserwować, że w kraterach widnieje pozostałość materiału stopu cyny (jaśniejsza barwa), który oderwał się od nieosadzonego ziarna, tworzącego krater. Stanowi to dowód na silne uplastycznienie materiału w wyniku tarcia oraz powstanie lokalnych mostków sczepnych, świadczących o połączeniu metalurgicznym. Porównanie zdjęć z eksperymentu do wyników z modelu wykazuje znaczne podobieństwo, szczególnie w dwóch ostatnich próbach, gdzie uzyskano najwyższą energię procesu. Można na nich znaleźć silnie odkształcone cząstki z dużą wypływką, zbliżone kształtem do zdjęć z modelu.
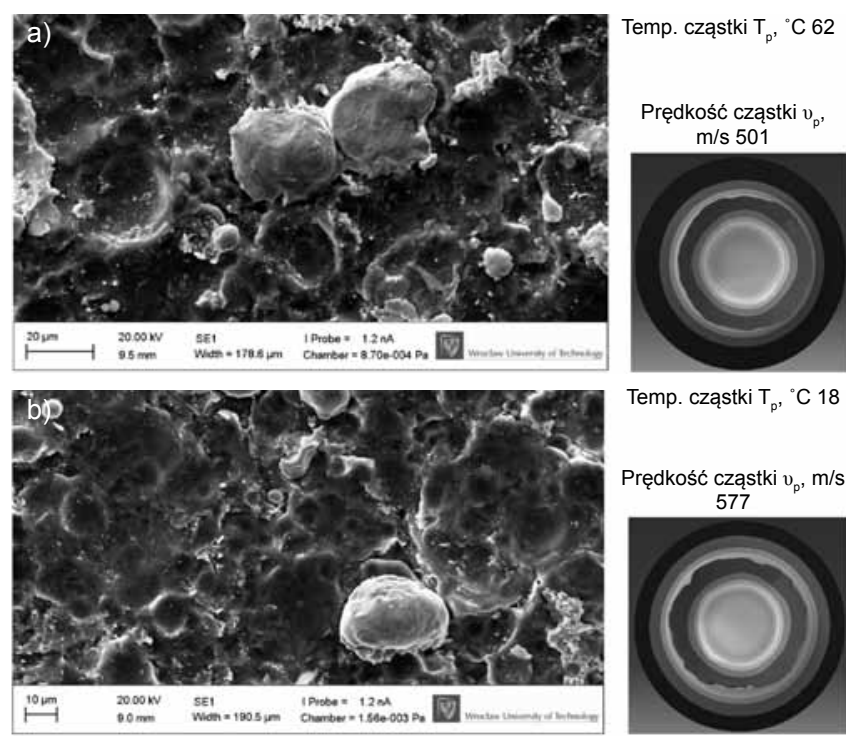

Temp. cząstki T ${ }^{\circ} \mathrm{C} 18$

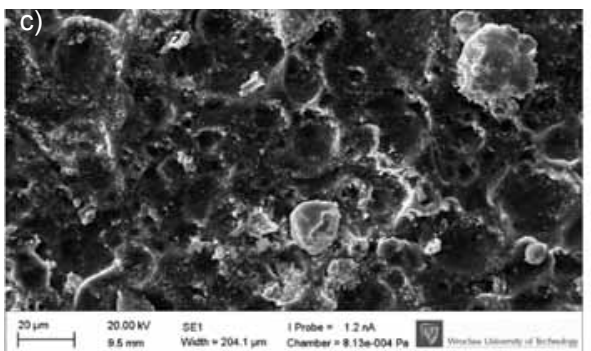

Prędkość cząstki v, m/s

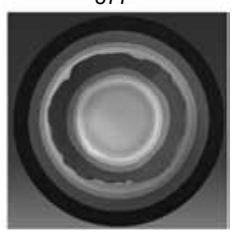

Temp. cząstki $\mathrm{T}_{\mathrm{p}},{ }^{\circ} \mathrm{C} 59$

Prędkość cząstki $v_{\mathrm{p}}, \mathrm{m} / \mathrm{s}$

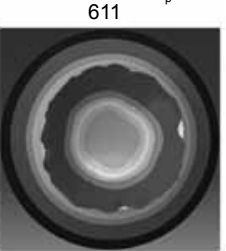

Rys. 11. SEM naniesionych cząstek oraz kształt cząstki z modelu w poszczególnych próbach: a) 2, b) 5, c) 6

Fig. 11. SEM view of the particles and it shape in the model in samples: a) 2, b) 5, c) 6

\section{Wnioski}

Analizując otrzymane wyniki, można wyciągnąc następujące wnioski:

- w chwili uderzenia cząstki w podłożu tworzy się krater;

- średnica i głębokość krateru wzrasta proporcjonalnie do prędkości cząstki oraz czasu kontaktu cząstki i podłoża, natomiast stosunek wysokości do szerokości osadzonej cząstki maleje;

- odkształcenie plastyczne cząstki oraz podłoża koncentruje się w określonych obszarach otaczających powierzchnię elementów, w wyniku czego tworzy się wypływka zmiękczonego i uplastycznionego materiału;
- w obszarze styku, gdzie występują największe odkształcenia, w wyniku tarcia dochodzi do znacznego wzrostu temperatury;

- wraz ze wzrostem prędkości grubość wypływki powierzchniowej zmniejsza się, wywołując wzrost naprężeń plastycznych zlokalizowanych w obszarze styku;

- cyna ma większą gęstość od aluminium, dlatego uderzenie cząstki wywołało głęboki krater o dużej średnicy dla każdej zadanej prędkości;

- duża plastyczność cyny przy jej dużej gęstości prowadzi również do powstania długiej, cienkiej wypływki.

\section{Literatura}

[1] King P.C., Bae G., Zahiri S.H., Jahedi M., Lee C.: An Experimental and Finite Element Study of Cold Spray Copper Impact onto Two Aluminum Substrates, Journal of Thermal Spray Technology, vol. 19 (3), 2010, s. 620-634.
[2] Kang K. C., Yoon S. H., Ji Y. G., Lee C.: Oxidation Effects on the Critical Velocity of Pure Al Feedstock Deposition in the Kinetic Spraying Process, Thermal Spray 2007: Global Coating Solutions (ASM International), 2007. 
[3] Li C.-J., Li W.-Y., Y.-Y.: Wang, Effect of Spray Angle on Deposition Characteristics in Cold Spraying, Thermal Spray 2003: Advancing the Science and Applying the Technology, (ASM International), 2003.

[4] Ghelichi R., Bagherifard S., GuaglianoM. , Verani M.: Numerical simulation of cold spray coating, Surface \& Coatings Technology, 205, 2011, pp. 5294-5301.

[5] Li W.-Y., Gao W.: Some aspects on 3D numerical modeling of high velocity impact of particles in cold spraying by explicit finite element analysis, Applied Surface Science, 255, 2009, s. 7878-7892.

[6] Dykhuizen R.C. and Smith M.F.: Gas Dynamic Principles of Cold Spray, Journal of Thermal Spray Technology, vol. 7 (2), 1998, s. 205-212.

[7] Staniszewski B.: Termodynamika, Państwowe Wydawnictwo Naukowe, Warszawa, 1982.

[8] Szargut J.: Termodynamika techniczna, Wydawnictwo Naukowe PWN, Warszawa, 1991.

[9] Ning X.-J., Wang Q. -S., Ma Z., and Kim H. -J.: Numerical Study of In-flight Particle Parameters in Low-Pressure Cold Spray Process, Journal of Thermal Spray Technology, vol. 19 (6), 2010, s. 1211-1217.
[10] Li W.-Y., Liao H., Douchy G., Coddet C.: Optimal design of a cold spray nozzle by numerical analysis of particle velocity and experimental validation with $316 \mathrm{~L}$ stainless steel powder, Materials and Design, vol. 28, 2007, s. 2129-2137.

[11] Champagne V.K.: The cold spray materials deposition process - Fundamentals and applications, Woodhead Publishing Limited, Cambridge, 2007.

[12] Tobias Schmidt, Hamid Assadi, Frank Gartner, Horst Richter, Thorsten Stoltenhoff, Heinrich Kreye, Thomas Klassen: From Particle Acceleration to Impact and Bonding in Cold Spraying, Journal of Thermal Spray Technology, vol. 18 (5-6), 2009, s. 794-808.

[13] Pawlowski L.: Science and engineering of thermal spray coatings, John Wiley \& Sons, Chichester, 2008.

[14] Schmidt T., Gärtner F., Assadi H., and Kreye H.: Development of a Generalized Parameter Window for Cold Spray Deposition, Acta Mater. 54, 2006, s. 729-742.

[15] Fei Q., Tong A., Na C.: Strain rate effect and Johnson-Cook models of lead-free solder alloys, International Conference on Electronic Packaging Technology \& High Density Packaging, 2008.

Artykuł powstał dzięki badaniom finansowanym przez Narodowe Centrum Nauki w ramach projektu nr 2011/01/N/ST8/04975, pt. „Adhesive properties of various material coatings deposition with low-pressure cold spray-ing”.

\section{POLSKIE TOWARZYSTWO SPAWALNICZE - ODDZIAL W OPOLU ORGANIZUJE W DNIACH 17 - 19 WRZEŚNIA 2013 r. WYJAZD NA TARGI SPAWALNICZE W ESSEN (NIEMCY)}

Uczestnikom wyjazdu zapewniamy:

- Przejazd komfortowym autokarem na trasie Opole - Essen - Opole i dojazdy na targi.

- Pełne wyżywienie, noclegi w hotelu (pokoje 2-osobowe, łazienka, WC, TV, telefon).

- Ubezpieczenie zagraniczne.

Prosimy o jak najszybsze wstępne powiadomienie o chęci wyjazdu. W kolejnym ogłoszeniu podany zostanie koszt uczestnictwa oraz szczegółowe dane dotyczące wyjazdu. Informujemy, iż przypadku większej ilości chętnych o rezerwacji miejsca decydować będzie kolejność zgłoszeń.

Więcej informacji można uzyskać u organizatorów:

Bienias Zygmunt, tel. +48 502096 917, e-mail: zygmunt.halina@wp.pl

Derwich Tomasz, tel. +48 774019258, e-mail: tomasz.derwich@esab.pl 